\title{
Research on College Students' Etiquette Driving Method
}

\author{
${ }^{I}$ College of Economics and Administration, Taizhou University, 225-300 China \\ ${ }^{2}$ College of Computer Science and technology, Taizhou University, 225-300 China \\ a1121561926@qq.com \\ *corresponding author
}

Shuxin Zheng ${ }^{1, \mathrm{a},{ }^{*}, \text { Bin Zhang }}{ }^{2}$, Weiwei $\mathrm{Xu}^{2}$ and Zhongguo Zhang ${ }^{2}$

\begin{abstract}
Based on the full analysis of the reasons for the lack of college students' etiquette and image, this paper is aimed to construct the force field system that drives college students' etiquette teaching and to proposes specific solutions. The experimental system is built with the students taught as the research objects, and the experimental research on the internal driving force is carried out and good results have been achieved.
\end{abstract}

Keywords: college students etiquette, Luin force field, Hawthorne effect, driving force

\section{THE CURRENT STATUS OF COLLEGE STUDENTS ETIQUETTE}

\begin{abstract}
With the continuous enhancement of the country's economic strength, our country has invested more and more in education and paid more and more attention to the quality of student training, which has greatly improved the popularizing rate of education in China and obviously improved the skills and basic qualities of Chinese citizens. However, from the perspective of the college education, the overall image of college students, especially the promotion of behavior and etiquette, there is still great space for improvement. With the ascension of China's international status and strong growth of the economy in our country, there is a large gap between the level of the etiquette image of the college students and that of the requirement of social and economic development, the main behavior are insufficient credit consciousness, difficulties in communication, especial the behavior lack of manners such as etiquette, or even affect the basic image of the intellectuals.
\end{abstract}

\section{REASONS FOR THE LACK OF ETIQUETTE OF COLLEGE STUDENTS}

Historical and cultural reasons. Due to China's long history, complicated development process, there are many improper interpretation of sinology, leading many people to question sinology. In addition, since the opium war, due to the invasion of foreign powers, many people with social influence wanted to make China rise by learning foreign countries' culture, so they blindly rejected our culture accumulated for thousands of years completely and accepted foreign culture completely without any choice. The others is due to the invasion of foreign cultures. Due to the backwardness of the government of the republic of China, foreign cultures took root and germinated in China. The wrong idea of "all foreign things are good" led to the super inferiority of Chinese people, which continues to this day. The most typical example is the 'civilized stick'. It was introduced into China by the western walking stick and changed its name to "civilized stick". It did not have the connotation of cultural etiquette. The reason why it symbolizes a higher civilization is simply because it was introduced into China by the west. Coupled with the input of many foreign films and TV dramas, many young students blindly believe that the foreign culture represents a higher level of civilization. This edge ideology makes the college students pursuit "western-style freedom, advocating release self", and lose the real self, and then forget our own powerful national culture, and makes part of our young students feel lack of confidence to thousands of years of traditional Chinese culture.

Comrade Xi-jinping put it in his report to the 19th national congress: "to realize our great dreams, we must advance our great cause and the whole party should be more consciously confident in its path, theory, system and culture." Colleges and universities shoulder the important mission of cultural inheritance and cultural construction, and students are the inheritors and disseminators of national culture. Therefore, we want to clearly carry forward our ancient national culture, firmly opposed to the denial of the ancient etiquette culture, regain cultural confidence, let our young students become cultural, understand the etiquette of the dream, shoulder the responsibility of national rejuvenation.

Environmental and educational reasons. The environment that contemporary university student faces is complex and changeful, and is full of temptation and crisis. Good and evil media information mixed up, electronic books filled with student's living space, all of these lead them to read less, many plays and games make the students lifestyle fragmentation, so it's very difficult to establish correct outlook on life, the formation of stable values [1], it can result in conflicts with the civilization etiquette in the students : dress blindly imitate the stars, they do not pay any attention to the occasion and environment-bare midriffs, backless across, decadent makeup look, violence, network language form abnormal recognition of beauty, fashion in campus,. This causes students to run counter to the etiquette culture. At the same time, with the improvement of our living standards, college students' enthusiasm and desire for wealth is beyond the normal level, and is accelerating the evolution process of "interests over etiquette" that seriously affected the formation of correct and even normal values of college students.

The lack of etiquette culture education is another important factor. China's family education is an important reason for 
the lack of etiquette culture education. First of all, due to the special historical stage of China, many parents grew up in a poor environment, resulting in serious psychological compensation. They gave more and better material conditions to students, but ignored the comprehensive education of children, and more of them expressed their love for their children with material pay instead of irrational education of their physical and mental growth. At the same time, children's order etiquette study period, the students are in the early stage of the reform and development in our country, parents spend more time and energy for the generation of data acquisition, improve their living condition, neglecting the most important values in the early period of construction, causes students failed to form their own correct values and lead to the behavior of the college students to follow and no definite view, blindly learning western advocated freedom, want to get rid of all imprisonment and bondage, many college students a strong sense of self, cooperation consciousness is poor, stubborn character, lead to interpersonal conflicts in the state is the outstanding performance, for the children to accept the positive energy,Creating a good personal culture creates a lot of resistance.Secondly, due to the cultural discontinuity, parents' knowledge of etiquette culture is also relatively weak, unable to assume the responsibility of etiquette education;Last and the most common is the fact that the order of education "' - when children are easy to phase inversion phenomenon, should is to cultivate children good habits and customs, etiquette courtesy, work life, emotions, parents are back to the tang dynasty, to learn to read and count, English with the cultivation of knowledge and skills, and by the middle school, the university will ask them how to speak, and ask them how polite, respect people. This 'inversion phenomenon' is common in China's family education model[2].

Educational institutions.Schools lack of etiquette culture theory support, the etiquette education become a mere formality, the etiquette related courses are set into the course, consideration is more of a professional class scores, ignoring the cultivation of the etiquette culture, at the same time, the teachers themselves to etiquette culture value degree is low, to own request is not high, not good for students to play the role of demonstration, lead to students in cultural etiquette knowledge value degree is low, shallow understanding degree and not solidify the etiquette culture into their own behavior, and become a part of the individual cultural quality.

\section{BUILD THE WAY TO SOLVE PROBLEMS}

Create a good external driving environment. Every citizen has the responsibility and obligation to contribute their own strength for the future development of the motherland. To promote the etiquette culture into the community and etiquette culture into the family activities and strengthen the education of children's etiquette culture in schools and other educational institutions, the Chinese nation's excellent etiquette culture tradition in our generation will brand 'The Times mark' . To establish and perfect the theoretical system, strengthen educational faculty and the study of practical courses, the best learning etiquette culture will be rooted in the elementary education stage, including kindergarten and elementary school. To guide students to learn and absorb classic parts of sinology, regain sinology, rebuild self-confidence, and establish correct values and outlook on life can promote the comprehensive development of college students, and improve their comprehensive competitiveness of college students and the comprehensive quality of Chinese citizens, and improve the value system of college students.

In the process of organizing students to learn etiquette culture, Redding's learning model is used[2,3] to enhance the internal driving force of students' learning. John Redding model believes that study and work are inseparable. Learning organization emphasizes learning in action, preparing while learning, planning while learning, and implementing while learning. The study of etiquette culture, throughout the preparation, planning and implementation of each stage, which with our ancestors in the Analects of Confucius said "Learning and constant practice" has the same wonderful. At the same time, parents take the initiative to cooperate with the school- the two sides work together to train the children. Make use of Rosenthal effect and Hawthorne effect to make students clear the goal of etiquette, and by the assessment, evaluation, rewards and punishments to the students, we can make students consciously learn and apply the etiquette, and ensure that the etiquette culture in the behavior of college students solidified.

\section{DRIVING METHODS AND EXPERIMENTAL RESEARCH}

This paper analyzes the feasibility of the proposed method with the help of Luin force field learning method. According to Luin, everything is in equilibrium with a pair of opposing forces including driving force and restrain force-a dynamic system in balance. In order for change, the driving force must exceed the restrain force, to break the balance.

The analysis diagram of the Luin force field is shown in figure 1. Force field analysis diagram is a graph analysis model based on these forces and reaction forces [4]. These forces include organizational membership, behavior, organizational customs and attitudes. Force-field diagrams are applicable to the analysis of change forces at different levels, such as individuals, projects, organizations, networks, etc., and can help identify forces that promote or hinder change. What a force field diagram means is that the same thing suffers from all the different forces and changes accordingly. 


\section{Force Field Diagram}

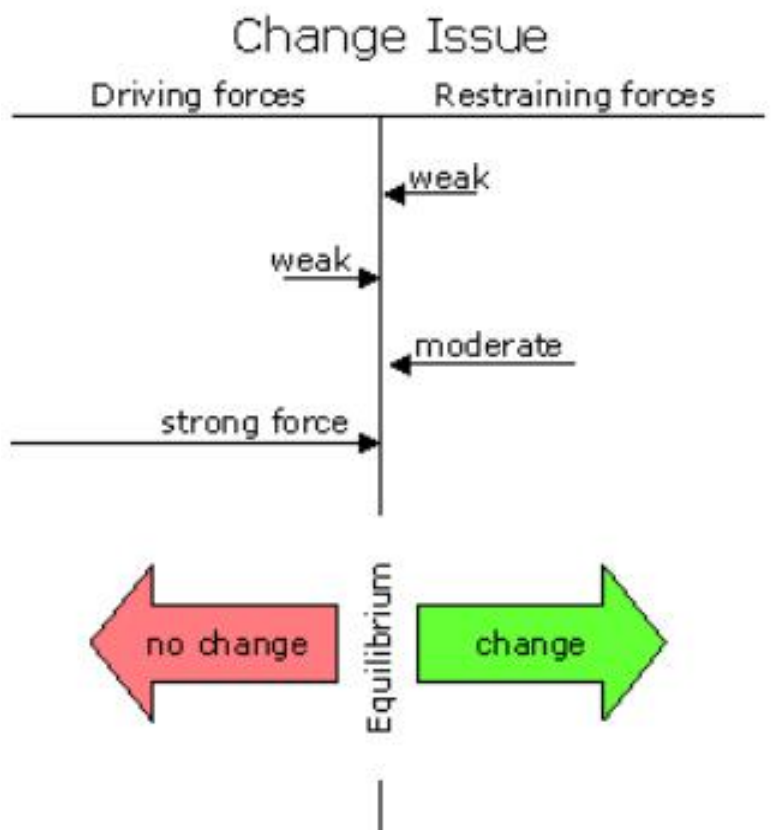

Figure 1 Luin's force field analysis

Specific program. Students are divided into two groups, evaluated the ordinary performance of each group, and found out the superior ones from each group to form an experimental group in secret for experimental members, We consciously let students participate in some activities or participate in some specific things or certain items to choose the subjects.Then, the individual behavior drive and organizational behavior drive are studied in the form of project.

Individual behavior driven research. According to the table 1, teachers gave the scores of the experimental group students according to the corresponding experimental items and the score of $\mathrm{A}$ is obtained, and the score of each index is between 1 and 10. It should be noted that in the process of the experiment, all the audio and video materials and paper materials of all the experimental items of the experimental students must be kept for the analysis. For example, during the etiquette evaluation of a certain student $\mathrm{X}$, we can take a photo of her typical dress with an unknown circumstances of the research, keep a recording of the phone conversation between the student and you, and take a representative video video when communicating with teachers and classmates face to face. Specific implementation is as follows.

Table 1 Student group behavior score table

\begin{tabular}{|c|c|c|c|c|c|}
\hline $\begin{array}{l}\text { Participatin } \\
\text { g students }\end{array}$ & $\begin{array}{c}\text { Dress } \\
\text { etiquette }\end{array}$ & $\begin{array}{l}\text { Talking to the } \\
\text { teacher }\end{array}$ & $\begin{array}{l}\text { Talking to } \\
\text { classmates }\end{array}$ & $\begin{array}{l}\text { Communic } \\
\text { ate with the } \\
\text { teacher }\end{array}$ & $\begin{array}{l}\text { Communic } \\
\text { ate with } \\
\text { classmates }\end{array}$ \\
\hline $\mathrm{X} 1$ & A11 & A12 & A13 & A14 & A15 \\
\hline $\mathrm{X} 2$ & A21 & A22 & A23 & A24 & A25 \\
\hline X3 & A31 & A32 & A33 & A34 & A35 \\
\hline$\ldots \ldots$ & $\ldots \ldots$ & $\ldots \ldots$ & $\ldots \ldots$ & $\ldots \ldots$ & $\ldots \ldots$ \\
\hline
\end{tabular}

Under the premise of obtaining the consent of the experimental group members, the relevant materials are taken as examples to implement classroom teaching, so that the students can watch and distinguish the inappropriate etiquette expressions in the behavior, propose improvement measures, and finally the teacher can make a correct demonstration.
On the premise of obtaining the consent of members of the experimental group, take relevant materials as examples, implement classroom teaching, let students watch and distinguish improper etiquette expressions, and propose improvement measures, and finally make correct demonstration in behaviors by the teacher.

Forced drive. According to table1, students are required to 
perform the three weeks or more well according to the accepted manners and encouraged and guided in the implementation process.

Solidified etiquette behavior. In the whole teaching semester, the students are divided into several groups, and the students are trained and practiced consciously according to different items. The teachers conduct the check and evaluation in effect. Using Hawthorne effect[5,6], all the teachers give full recognition to the students whose behaviors should be written into the notebook to record, the etiquette items are compiled into a rush to answer questions that the students can give the correct answers, who will be rewarded and issued certificates by the form of activities

Assessment and evaluation. At the end of the semester, the corresponding items of students will be evaluated and compared with those at the beginning of the experiment to form self - excitation as follow.

$$
X=k_{1} A_{11}+k_{2} A_{12}+k_{3} A_{13}+\ldots .
$$

$\mathrm{k}$ is the weighting factor of the item being examined, and $\mathrm{x}$ is the etiquette comprehensive score of a student in formula(1).

$$
P=\frac{X^{\prime}-X}{X} \times 100 \%
$$

The $p$ in the formula(2) is the degree of progress after one semester promotion and training, and $\mathrm{x}^{\prime}$ and $\mathrm{x}$ are the ceremonial comprehensive scores at the end of the semester and the beginning of the semester, respectively. The value of $\mathrm{p}$ greater than $50 \%$ goes directly to the next experimental study-tissue behavior-driven experiments. Students whose P value is greater than $30 \%$ but less than $50 \%$, scenario teaching will be conducted and students whose $\mathrm{P}$ value is less than $30 \%$ according to corresponding target training. After the all value of $\mathrm{P}$ are greater than $50 \%$, the experiment is carried out to drive organizational behavior. Organizational behavior drives experimental research. There are many ways to drive organizational behavior. Here, take the estern dining etiquette as an example. Let the students value of $\mathrm{P}$ be greater than $50 \%$ go to the western restaurant to have a meal in the way of AA, videotape the whole process of the meal of students in the experimental group, and then return to the classroom for analysis and correction. The students with well western etiquette as a model, and the models is divided into a group of five, each group with three non-model students, using the power of the organization to make students into the etiquette environment, follow, simulate dining etiquette, and then in the future the behavior will be in implementation, solidification.

\section{CONCLUSION}

Through the implementation of the two experimental sessions of this article, and after one semester of persistence, compared with the control group, the etiquette level of each classmate in the experimental group has been greatly improved, and through the practice of the students and the encouragement of the teachers, more than half of the classmates can solidify some of their etiquette behavior into their daily lives. At the same time, in the process of teaching practice, the students did not have a psychological burden. Instead, in the process of educating students in etiquette culture, they guided students to be more confident in themselves and greatly improved their interest and importance to etiquette, and received well effect and achieved the purpose.

\section{ACKNOWLEDGMENT}

This work was supported by the university natural science project(No.19kjd120002 ), Jiangsu, China.

\section{REFERENCES}

[1] Weiwei Xu ,Shuxin Zheng ,Zhongguo Zhang .The Application of Fuzzy Decision in the Management for Undergraduates[A].Proceedings of the 2018 International Symposium on Social Science and Management Innovation:291-296.

[2] Guan li. and group dynamics [J]. Management modernization, 1989(04):50-51.

[3] XU Wei-wei. Research on Educational Management Method of "3+4" Sectional Training Model in Jiangsu Province", Journal of taizhou vocational and technical college. 2019(2):9-11+54.

[4] $\mathrm{Xu}$ guangyin, Chen xinping, li qiuxiang, zhang hui. Application of force analysis in self-management decision of logistics $[\mathrm{J}]$. Logistics science and technology,2006(01):89-91.

[5] Chen jiajia. Reflection and exploration on strengthening college students' etiquette cultivation [J]. Reform and opening up,2018(22):149-150.

[6] Mao wanxin. On the lack of etiquette cultivation of college students and countermeasures.[J]. Modern communication, 2019(08):128-129 